\title{
The Failure in NGF Maturation and its Increased Degradation as the Probable Cause for the Vulnerability of Cholinergic Neurons in Alzheimer's Disease
}

\author{
A. Claudio Cuello $\cdot$ Martin A. Bruno
}

Published online: 1 September 2007

(C) Springer Science+Business Media, LLC 2007

Erratum to: Neurochem Res

DOI 10.1007/s11064-006-9270-0

Due to an oversight, this article, which was submitted for the present special issue, has been published in a previous issue of the journal-Vol. 32, No. 6, pp. 1041-1045. The editor regrets this error.

The online version of the original article can be found under doi: 10.1007/s11064-006-9270-0

A. C. Cuello $(\bowtie) \cdot$ M. A. Bruno Departments of Pharmacology \& Therapeutics, McGill

University, 3655 Promenade Sir-William-Osler, Montreal, QC, Canada H3G 1 Y6

e-mail: claudio.cuello@mcgill.ca

A. C. Cuello

Anatomy and Cell Biology, McGill University, Montreal,

Quebec, Canada H3G 1 Y6

A. C. Cuello

Neurology and Neurosurgery, McGill University, Montreal,

Quebec, Canada H3G 1Y6 